\title{
Controls on Temporal and Spatial Variation of Nutrients in a Tropical Marine Artificial Reef: The Case of the Victory 8B on the Southeastern Brazilian Coast
}

\author{
Costa, E. S.;* Andrade, R. R.; Junior, L. B.; Gaigher, L. P.; Oliveira, C. M. S.; \\ Junior, C. D.; Neto, R. R.
}

Rev. Virtual Quim., 2014, 6 (4), 834-843. Data de publicação na Web: 22 de fevereiro de 2014

http://www.uff.br/rvq

\begin{abstract}
Controles sobre a Variação Temporal e Espacial dos Nutrientes em um Recife Artificial Tropical Marinho: O Caso do Victory 8B na Costa Sudeste do Brasil
\end{abstract}

Resumo: O objetivo deste estudo foi avaliar a distribuição temporal e espacial de nutrientes em torno do recife artificial marinho (MAR) 8B Victory, um navio afundado propositadamente em Guarapari (20 $40^{\circ}$ ' S e $40^{\circ} 30^{\prime} \mathrm{W}$ ), no estado do Espírito Santo, em uma das mais ricas áreas de biodiversidade marinha na costa brasileira. Oito cruzeiros trimestrais de um dia foram realizados por mais de dois anos (de março de 2005 a abril de 2007). As amostras foram coletadas em 12 estações diferentes ao redor do navio para a análise dos nutrientes inorgânicos dissolvidos (nitrito, nitrato, silício reativo e ortofosfato), clorofila a, phaeopigmentos, salinidade e temperatura. Correlações de ortofosfato e clorofila podem indicar que ele é limitante. As suas concentrações eram sempre baixas, o que pode ser devido à sedimentação de carbonato, pois a região é rica em sedimentos deste sal. Nutrientes nitrogenados foram enriquecidos, indicando que o MAR muda a dinâmica da água. Alternativamente, as ilhas próximas do navio também podem estar trabalhando como recifes, aumentando a concentração. Embora não tenha havido variação espacial significativa, mudanças sazonais controladas principalmente por direções atuais, rotas frias de entrada frontal e as chuvas foram encontradas, com uma influência menor da atividade biológica.

Palavras-chave: Clorofila-a (Chl a); Guarapari; Nutrientes; Correntes; Afloramento.

\begin{abstract}
The objective of this study was to evaluate the temporal and spatial nutrient distribution around the marine artificial reef (MAR) Victory $8 \mathrm{~B}$, a ship purposely sunk at Guarapari $\left(20^{\circ} 40^{\prime} \mathrm{S}\right.$ and $\left.40^{\circ} 30^{\prime} \mathrm{W}\right)$, Espírito Santo State, in one of the richest marine biodiversity areas on the Brazilian coast. Eight trimestral one-day cruises were carried out from March 2005 to April 2007. Samples were collected at 12 different stations around the ship for the analysis of dissolved inorganic nutrients (nitrite, nitrate, reactive silicon and orthophosphate), chlorophyll $a$, phaeopigments, salinity and temperature. Orthophosphate correlations to chlorophyll $a$ may indicate that it is limiting. Its concentrations were always low, which may be due to carbonate sedimentation, as the area is rich in calcium carbonate sediment. Nitrogenous nutrients were enriched, indicating that the MAR changes the water dynamics. Alternatively, islands nearby the ship may also be working as reefs to increase the concentration. Although there was no statistically significant spatial variation, seasonal changes controlled mainly by current directions, cold front entrance routes and rainfall were found, with a minor influence of biological activity.
\end{abstract}

Keywords: Chlorophyll a (Chl a); Guarapari; Nutrients; Currents; Upwelling.

\footnotetext{
* Universidade Federal do Espírito Santo, Departamento de Oceanografia e Ecologia, Av. Fernando Ferrari, 514, CEP 29075-910, Vitória-ES, Brazil.

Meduoceano@gmail.com DOI: $\underline{10.5935 / 1984-6835.20140051}$
}

Rev. Virtual Quim. |Vol 6| | No.4| |834-843| 


\title{
Controls on Temporal and Spatial Variation of Nutrients in a Tropical Marine Artificial Reef: The Case of the Victory 8B on the Southeastern Brazilian Coast
}

\author{
Eduardo S. Costa, * Rosana R. Andrade, Luciano Bazoni Junior, Lilian P. \\ Gaigher, Cristiane M. S. Oliveira, Camilo Dias Junior, Renato R. Neto
}

Universidade Federal do Espírito Santo, Departamento de Oceanografia e Ecologia, Av. Fernando Ferrari, 514, CEP 29075-910, Vitória-ES, Brazil.

* eduoceano@gmail.com

Recebido em 16 de agosto de 2012. Aceito para publicação em 22 de fevereiro de 2014

\section{Introduction}

2. Material and methods

3. Results

4. Discussion

5. Conclusions

\section{Introduction}

Marine artificial reefs (MARs) are structures purposely submerged in the sea floor to mimic some features of natural reefs ${ }^{1}$ and increase the concentration of nutrients, thereby increasing local primary productivity ${ }^{2}$, which can, in turn, cause an increase in the abundance of many typical species from rocky environments. MARs can be used for several purposes: for fishing ativities ${ }^{3}$, to mitigate impacts on previously degraded habitats ${ }^{4}$, to protect marine biodiversity by creating restricted fishing zones around these structures ${ }^{5}$, to control predatory fishing ${ }^{6}$, to improve water quality ${ }^{7}$ and to stimulate tourism of the region. ${ }^{8}$

There are several types of structures and materials that are placed on the seabed to form MARs. The most common include concrete blocks, steel tubes, tires, disabled oil platforms and ships. ${ }^{2}$ The material and structure of the reef directly influence the community that will colonize it, however, for the successful creation of the reef, it is important that the material be resistant and does not release pollutants.

Although studies on ecological and economic aspects of artificial reefs are common in some countries, as USA, Canada, Japan, France and Portugal, where MARs are commonly used in coastal management, studies related to the effects of chemical parameters on artificial reefs are rare. ${ }^{9}$

In Brazil, the use of artificial reefs is recent but rapidly growing. This is mainly due to the aid of government. In recent years, several studies for deployment of MARs, as well as the deployment of MARs itself, have been 
carried out, among which includes the study of the largest MAR in Latin America, which is formed by a merchant ship, the VICTORY $8 \mathrm{~B}$.

The Greek-flagged ship VICTORY 8B had been moored in the port of Vitória, city of Vitória, state of Espírito Santo, Brazil, in August 1997, when it was seized at the request of the Central Bank of Greece. As a consequence, the vessel could not leave the port of Vitória. After staying on the ship for two years, the crew ran out of fuel, water and food and then requested extradition to the Brazilian Federal Police. The State Department of the Environment incorporated the VICTORY $8 \mathrm{~B}$ to the Marine Artificial Reef Project (ES) in the same year.

The ship was sunk at $12 \mathrm{~km}$ from the coast of the city of Guarapari $\left(20^{\circ} 40^{\prime} \mathrm{S}\right.$ and $40^{\circ} 30^{\prime} \mathrm{W}$ ), state of Espírito Santo, Brazil, on $3^{\text {rd }}$ of July of 2003 . Victory $8 B(89.7 \mathrm{~m}$ long $x$ $13.6 \mathrm{~m}$ wide) is on the inner continental shelf ( $\sim 30 \mathrm{~m}$ deep), between the Escalvada and Rasas islands. This region was chosen to mitigate the impacts of predatory fishing and intense diving activities on the surrounding islands.

An oceanographic study (geology, chemistry, biology and physics) was carried out to evaluate the progress of the changes in abiotic factors caused by the deployment of the MAR VICTORY 8B. In this study, the chemical parameters (dissolved nutrients: orthophosphate, nitrite, nitrate and reactive silicon; physico-chemical variables: temperature, dissolved oxygen saturation, $\mathrm{pH}$ and salinity; and an indicator of phytoplankton biomass: chlorophyll $a(\mathrm{Chl} a)$ ) will be discussed. Thus, we aimed to study the spatial and temporal variations as well as the interrelationship of chemical parameters and the physical chemistry of the water column. These parameters can be used as important indicators when monitoring the environment, as not only they control the rate of primary productivity, but also indicate the environmental quality of the ecosystem.

\section{Material and methods}

Samples were collected 8 times over a period of two years (on $5^{\text {th }}$ of April, September, December, $6^{\text {th }}$ of April, July, October and $7^{\text {th }}$ of January and April) in 12 fixed stations distributed over four radials $\left(90^{\circ}\right.$ from each other) around VICTORY $8 B$ (Figure 1). Three points (A, B and C, at 100 , 500 and $1000 \mathrm{~m}$ from the vessel, respectively) were sampled in each radial. These distances were determinate by the State Department of the Environment. The water samples were collected on the surface and at the middle-water column-bottom (hereafter noted simply as bottom) using Niskin bottles, and thereafter the samples were stored in polyethylene bottles and kept refrigerated for transport to the laboratory, where they were kept frozen at $-20^{\circ} \mathrm{C}$.

Approximately $1,000 \mathrm{~mL}$ of water collected from each sample was filtered (with a membrane filter of cellulose acetate with $0.45 \mu \mathrm{m}$ pores), divided into 4 aliquots of 250 $\mathrm{mL}$ and frozen for the analysis of dissolved nutrients. For the determination of dissolved inorganic nutrients (orthophosphate, nitrite, nitrate and reactive silicon), the methodology described by Aminot and Chaussepied (1983) was used. ${ }^{10}$

Analyses were carried out in triplicate for each sample. The analytical curves for all nutrients showed $R^{2}>0.99$, and the methods for phosphate, nitrite and nitrate were tested against solutions purchased from LabSolutions, showing errors lower than $15 \%$.

Chemical and physical parameters (temperature, dissolved oxygen and saturation, $\mathrm{pH}$, salinity and conductivity of water) were determined in situ at five different depths $(\approx 0,5,10,15$ and $20 \mathrm{~m})$ using a multiparametric probe (YSI 556 MPS). Current directions were determined by leaving the boat adrift during the samples collection on each station. In this time, was used the GPS location to verify which direction the boat has drifted. 


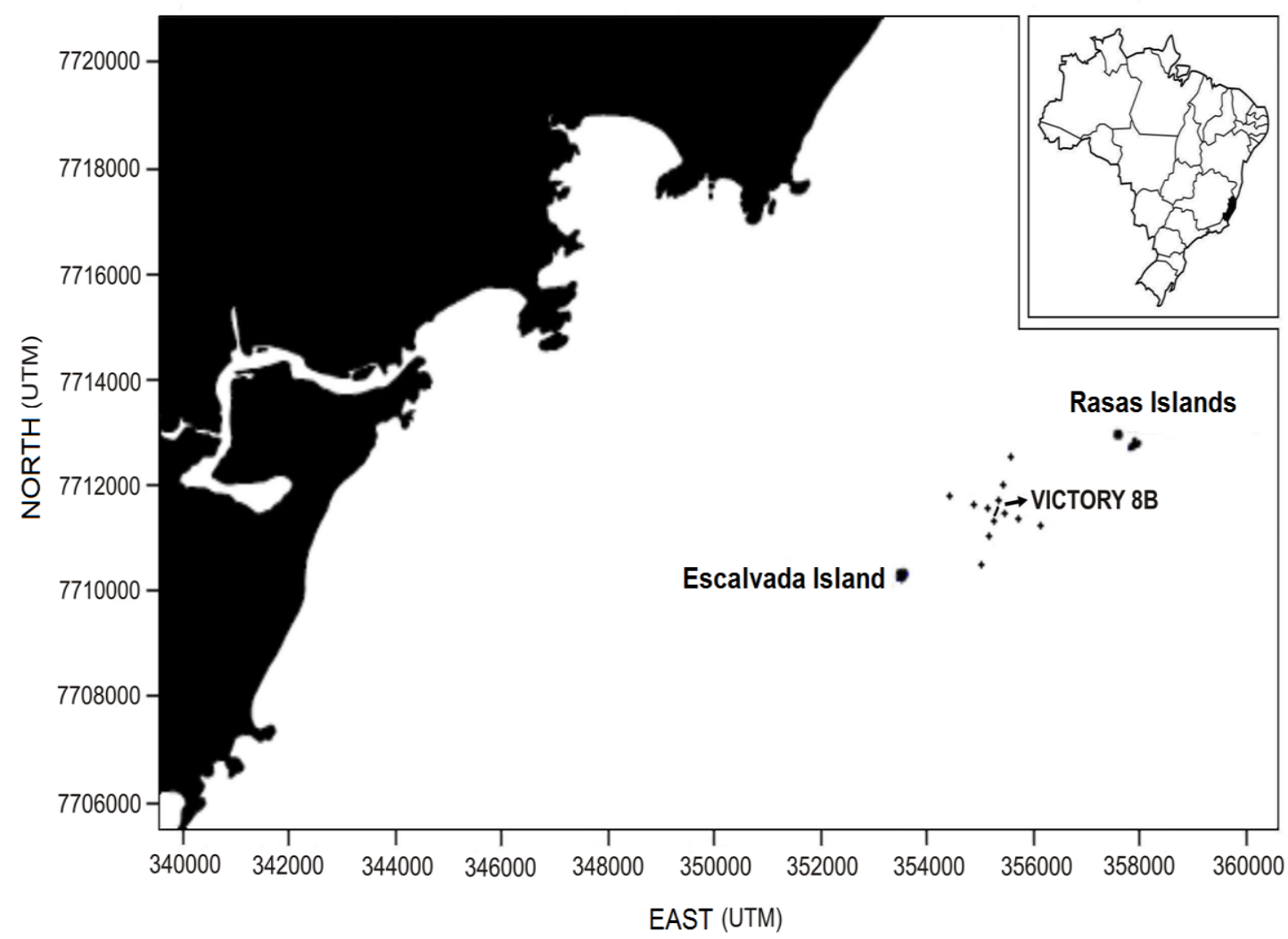

Figure 1. Stations around the MAR Victory 8B at Guarapari's Coast (the Espírito Santo State is in black at the top right corner)

Samples for the analysis of chlorophyll $a$ were also taken with Niskin bottles from the surface and bottom at each sampling station. Volumes of $500 \mathrm{~mL}$ were filtered (Whatman GF/F) from each sample, and the concentrations of chlorophyll $a$ were determined using a Fluorimeter ${ }^{11}$, with the final concentrations obtained by the arithmetic mean of the values from the Fluorimeter readings of samples and their replicates.

Univariate analyses of variance (oneway ANOVA) were used to compare chemical and physical-chemical parameters among the sites and times sampled. The Spearman correlation test was used to verify the influence of the physic-chemical parameters on nutrients. Only results with $p<0.05$ were considered to be significant.

\section{Results}

Currents showed the following directions: south ( $1^{\text {st }}$ Campaign), north ( $2^{\text {nd }}$ Campaign), west $\left(3^{\text {rd }}\right.$ Campaign), southwest $\left(4^{\text {th }}, 5^{\text {th }}, 6^{\text {th }}\right.$, $7^{\text {th }}$, and $8^{\text {th }}$ Campaigns). Although currents varied direction, 5 out of 8 times were southwest.

The concentrations of nutrients showed no statistically significant differences among sampling stations or depths (differences between radials and equidistant points for inter- and intra-cruises). However, there was a significant temporal variation over the eight campaigns for all nutrients (ANOVA $P$ $<0.001)$. Because of this, the data are shown as campaign averages. Tables 1, 2 and 3 show the results for the nutrient concentrations, physical and chemical parameters and statistically significant spearman correlations, respectively. 
Table 1. Range, average and standard deviation (SD) of the concentrations of dissolved inorganic nutrients

\begin{tabular}{|c|c|c|c|c|c|}
\hline Campaigns & Statistics & $\begin{array}{l}\mathrm{PO}_{4}^{3-} \\
(\mu \mathrm{M})\end{array}$ & $\begin{array}{l}\mathrm{NO}_{2}^{-} \\
(\mu \mathrm{M})\end{array}$ & $\begin{array}{l}\mathrm{NO}_{3}^{-} \\
(\mu \mathrm{M})\end{array}$ & $\begin{array}{c}\mathrm{H}_{3} \mathrm{SiO}_{4} \\
(\mu \mathrm{M})\end{array}$ \\
\hline \multirow{3}{*}{$1 \mathrm{a}$} & Range & $0.03-0.20$ & $0.23-0.56$ & $2.60-5.59$ & $0.74-13.90$ \\
\hline & Average & 0.11 & 0.35 & 3.72 & 3.09 \\
\hline & SD & 0.05 & 0.07 & 0.56 & 2.68 \\
\hline \multirow{3}{*}{$2^{a}$} & Range & $0.03-0.20$ & $*-0.20$ & $0.48-1.00$ & $37.56-172.23$ \\
\hline & Average & 0.07 & 0.13 & 0.76 & 74.61 \\
\hline & SD & 0.04 & 0.05 & 0.16 & 32.08 \\
\hline \multirow{3}{*}{$3 a$} & Range & $0.15-1.38$ & $0.31-0.54$ & $8.58-31.41$ & $2.74-8.38$ \\
\hline & Average & 0.37 & 0.4 & 15.46 & 5.12 \\
\hline & SD & 0.25 & 0.06 & 7.05 & 1.58 \\
\hline \multirow{3}{*}{$4 \underline{a}$} & Range & $0.08-1.51$ & $0.06-0.34$ & $4.55-9.29$ & $0.17-4.61$ \\
\hline & Average & 0.25 & 0.16 & 6.06 & 2.04 \\
\hline & SD & 0.29 & 0.07 & 1.28 & 1.31 \\
\hline \multirow{3}{*}{5} & Range & $0.33-1.79$ & $0.24-0.89$ & $5.39-16.58$ & $4.14-40.15$ \\
\hline & Average & 1.19 & 0.52 & 9.25 & 12.07 \\
\hline & SD & 0.26 & 0.24 & 3.56 & 7.43 \\
\hline \multirow{3}{*}{$6 a$} & Range & $0.76-1.32$ & $0.14-0.72$ & $2.68-5.27$ & $15.21-31.74$ \\
\hline & Average & 1.00 & 0.36 & 3.97 & 21.15 \\
\hline & SD & 0.14 & 0.13 & 0.67 & 4.26 \\
\hline \multirow{3}{*}{$7 \mathfrak{a}$} & Range & $0.35-0.76$ & $0.04-0.86$ & $1.26-2.07$ & $9.67-24.78$ \\
\hline & Average & 0.49 & 0.13 & 1.48 & 14.80 \\
\hline & SD & 0.09 & 0.16 & 0.18 & 3.83 \\
\hline \multirow{3}{*}{$8 \mathrm{a}$} & Range & $0.02-1.41$ & $0.45-0.86$ & $10.06-21.40$ & $1.18-16.41$ \\
\hline & Average & 0.31 & 0.58 & 15.47 & 5.12 \\
\hline & SD & 0.26 & 0.14 & 2.50 & 4.45 \\
\hline
\end{tabular}

* Below detection limit $(0.02 \mu \mathrm{M})$ 
Table 2. Range, average and standard deviation (SD) of values of the physical and chemical parameters

\begin{tabular}{|c|c|c|c|c|c|c|}
\hline Campaigns & Statistics & Chlorophyll $a$ & $\begin{array}{l}\text { Phaeo- } \\
\text { pigments }\end{array}$ & Temperature & Salinity & Conductivity \\
\hline \multirow{3}{*}{$1 \underline{a}$} & Range & $0.28-0.66$ & $0.11-0.55$ & $24.39-26.70$ & $*$ & $*$ \\
\hline & Average & 0.55 & 0.29 & 25.23 & $*$ & $*$ \\
\hline & SD & 0.10 & 0.10 & 0.50 & $*$ & $*$ \\
\hline \multirow{3}{*}{2} & Range & $0.16-0.52$ & $0.10-0.49$ & $21.93-22.43$ & $*$ & $*$ \\
\hline & Average & 0.38 & 0.22 & 22.06 & $*$ & $*$ \\
\hline & SD & 0.11 & 0.09 & 0.14 & $*$ & $*$ \\
\hline \multirow{3}{*}{$3 \underline{a}$} & Range & $0.29-0.67$ & $0.00-0.43$ & $21.16-22.88$ & $34.40-37.80$ & $51.36-61.07$ \\
\hline & Average & 0.49 & 0.09 & 21.69 & 35.35 & 56.63 \\
\hline & SD & 0.12 & 0.12 & 0.56 & 0.93 & 3.21 \\
\hline \multirow{3}{*}{$4 \underline{a}$} & Range & $0.11-0.42$ & $0.00-0.09$ & $24.67-25.82$ & $36.04-37.72$ & 54.51-57.60 \\
\hline & Average & 0.15 & 0.05 & 25.56 & 36.98 & 56.19 \\
\hline & SD & 0.08 & 0.02 & 0.35 & 0.65 & 1.19 \\
\hline \multirow{3}{*}{5} & Range & $0.36-1.55$ & $0.07-0.41$ & $21.89-22.86$ & 36.63-36.96 & $52.27-53.34$ \\
\hline & Average & 0.81 & 0.22 & 22.16 & 36.94 & 52.50 \\
\hline & SD & 0.33 & 0.09 & 0.38 & 0.08 & 0.39 \\
\hline \multirow{3}{*}{ 6a } & Range & $0.18-0.52$ & $0.12-0.48$ & $21.95-22.59$ & $36.14-37.02$ & $52.06-53.15$ \\
\hline & Average & 0.33 & 0.20 & 22.17 & 36.94 & 52.61 \\
\hline & SD & 0.10 & 0.09 & 0.22 & 0.17 & 0.28 \\
\hline \multirow{3}{*}{$7 \underline{a}$} & Range & $0.40-1.05$ & $0.17-1.31$ & $21.89-22.44$ & $36.45-36.61$ & $51.87-52.30$ \\
\hline & Average & 0.76 & 0.35 & 22.14 & 36.57 & 52.09 \\
\hline & SD & 0.19 & 0.22 & 0.17 & 0.06 & 0.13 \\
\hline \multirow{3}{*}{$8 \underline{a}$} & Range & $0.16-0.80$ & $0.00-0.54$ & $23.23-23.78$ & $36.76-36.82$ & $53.60-54.14$ \\
\hline & Average & 0.31 & 0.14 & 23.42 & 36.81 & 53.80 \\
\hline & SD & 0.17 & 0.17 & 0.23 & 0.02 & 0.23 \\
\hline
\end{tabular}

*not determined 
Table 3. Rs values of the non-parametric correlations $(p<0.05)$

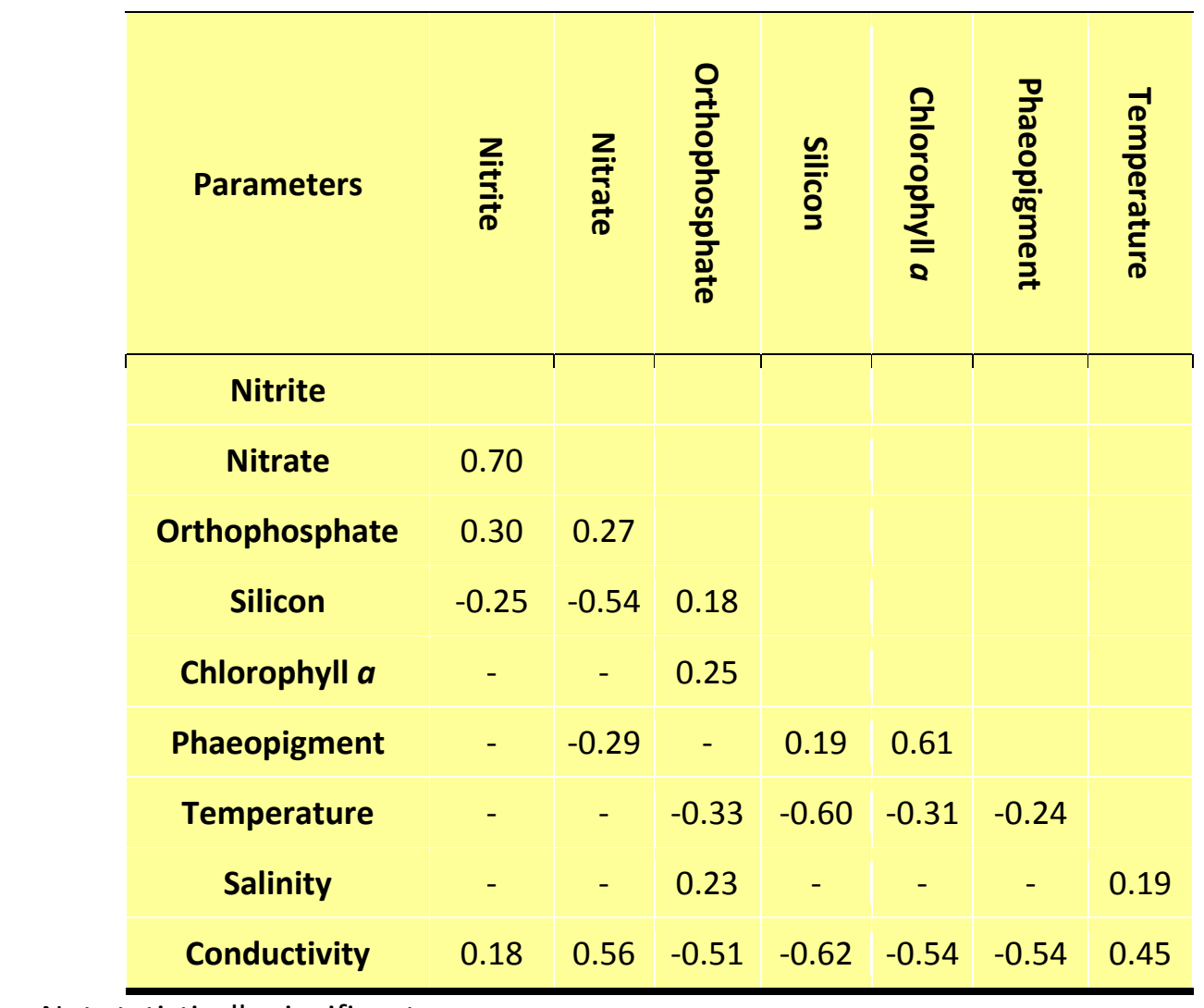

- Not statistically significant

\section{Discussion}

Comparing the concentrations of dissolved nutrients found around the MAR VICTORY $8 \mathrm{~B}$ to values found by Rezende et al. $(2006)^{12}$ during cruises in the central region of the Brazilian Exclusive Economic Zone (which includes the area of the VICTORY 8B), concentrations of orthophosphate and nitrite (0.06-4.51 $\mu \mathrm{M}$ and <0.02-1.44 $\mu \mathrm{M}$, respectively) were similar, but nitrate $(<0.05-$ $18.12 \mu \mathrm{M})$ and silicate $(<0.03-21.00 \mu \mathrm{M})$ presented values lower than those found in the MAR VICTORY-8B (Table 1). The nitrate values in Abrolhos Bank (north of Espirito Santo Coast) analyzed by Gaeta et al. (1999) ${ }^{13}$ (0.2-1.5 $\mu \mathrm{M})$ were also lower than those found in this study (Table 1). This divergence in the regional waters (which are characterized as oligotrophic) and the regions nearby the vessel indicates that the MAR may be influencing the local dynamics, thereby altering the distribution of nutrients. As explained by Wolanski et al. $(1995)^{14}$, when shallow water flows around an obstacle, the currents can generate eddies in the shadows of these barriers, which can generate upwelling within these eddies and downwelling at the edges. This can increase the sediment load and, as a consequence, the nutrients in the water column. This may be occurring at the Victory $8 \mathrm{~B}$ as noted by Falcão et al. $(2007)^{15}$, who observed an increase in the concentration of nutrients after the deployment of a MAR in Algarve in the south of Portugal over a two-year study. Another important aspect to be considered is that the VICTORY $8 B$ is located south of Três llhas Islands and between the Rasas Islands and Escalvada Island $(\approx 7.5, \approx 2$, and $\approx 2.8 \mathrm{~km}$ far from it, respectively; Figure 1 ). So, the increase of nitrogenous nutrients could also be associated with the events of island shades. These events also contribute to a similar increase of the nutrients in the water column as that seen with a MAR. These shades are often seen from above on board 
of airplanes. The concentrations of orthophosphate may be limiting to phytoplankton growing, as indicated by the statistically significant correlation, although weak, to chlorophyll a $(\mathrm{Rs}=0.25, \mathrm{P}<0.05$, Table 3). This concentration of orthophosphate could be explained as a consequence of several mechanisms which influence the removal of phosphorus, such as the precipitation of calcium phosphate granules and the adsorption of carbonate sediments of the bottom ${ }^{16}$, which are characteristic of the region around the MAR. Similar patterns were found by Falcão et al. (2007). ${ }^{15}$

In relation to seasonal variation, samples from the $3^{\text {rd }}$ and $8^{\text {th }}$ cruises showed higher levels of nutrients compared to samples from the others campaigns (except for dissolved silicon), namely for the high concentrations of nitrogenous nutrients found during the $3^{\text {rd }}$ cruise (Table 1). These values can be explained by the fact that the region may suffer from the influence of the Victoria Eddy $\left(20^{\circ} 30^{\prime} \mathrm{S}\right.$ and $\left.38^{\circ} 90^{\prime} \mathrm{W}\right)$, which corresponds to a cyclonic eddy characterized by a nucleus with relatively cooler and less saline water compared to the adjacent water that is probably related to the upwelling events. ${ }^{17}$ Gaeta et al. (1999) ${ }^{13}$ proposed that the Victoria Eddy is a permanent feature of the region, although with more pronounced upwelling events associated with summer and spring. Furthermore, they showed that the Victoria Eddy significantly contributes to the increase of the primary production in the region by analyzing the concentrations of nutrients and the phytoplankton biomass. Thus, the westward current on the days of sampling could be transporting a considerable supply of nutrients from the pumping of the South Atlantic Central Water (SACW - T $<20^{\circ} \mathrm{C}$ and $\mathrm{S}<36.4^{\circ} \mathrm{C}$ ) from the euphotic zone, providing high values in the water column. ${ }^{18}$ Reinforcing this idea, the data of temperature and salinity found during the $3^{\text {rd }}$ campaign were around 21.6 and $36.0^{\circ} \mathrm{C}$, respectively (Table 2 ). The relatively higher values of temperature may be due to the processes of mixing and heating during the upward movement of the body of water.

It is interesting that the highest correlations, albeit negative, to both temperature and conductivity were found for silicon (Table 3 ), which shows an association with terrestrial material and rainfall. On the $2^{\text {nd }}$ campaign, the concentrations of reactive silicon were high, which was probably because of a more intense input of terrigenous sediments due to a cold front entrance with significant rainfall during the week of sampling.

Comparing the correlations of nutrients to the indicators of temperature and salinity and biological processes (Chlorophyll $a$ and phaeopigments), the two formers is greater (Table 3). This indicates that the dissolved nutrients and their distributions are influenced mainly by physical processes such as currents, cold front entrances and rainfall. Large-scale movements of the marine environment carry bodies of water that are eventually associated with certain concentrations of nutrients. Thus, relatively cold water masses may present, in most cases, with an elevated nutrient concentration. ${ }^{19}$ Accordingly, the lowest concentrations were detected during the first cruise, when the current was southward as the Brazilian Current, which is characterized as oligotrophic. Then, as stated before, high concentrations of nitrogenous nutrients were sampled during the third campaign, when the currents were westward and were probably influenced by the Victoria Eddy and SACW upwelling. Finally, the highest values for dissolved reactive silicon were found after a cold front entrance with a northward current.

For comparison, the seasonal variations found in the concentrations of nutrients in the reef located in the Gulf of Aqaba (Red Sea) are not related to the currents. ${ }^{20}$ According to these authors, these variations are due to significant differences in the water temperature between winter and summer, and the high concentration values found in winter are caused by the mixing of the water column, which is responsible for removing the gradient of density. In the summer, low 
concentrations were due to the stratification of the water column that prevented the mixing of the superficial and deep layers. However, Ayukai $(1993)^{21}$ states that it is difficult to detect seasonal variations in the concentrations of nutrients, especially in reefs, as these variations usually occur over long sampling intervals but large variations occur over short times, as in this study.

\section{Conclusions}

The concentrations of nitrogenous nutrients around the Victory $8 \mathrm{~B}$ were relatively high. Although there is no past data about the chemical parameters in the study area, these high concentrations may suggest that the MAR is influencing the water column. Indeed, the deployment of artificial reefs creates a new structure for the colonization of different communities of organisms, resulting in increased local biomass (in situ observation, not published). It is also important to note that the islands that surround this MAR could also be responsible for this increase. Our results indicate that current direction, cold front entrances and rainfall may be the main factors controlling the distribution of nutrients on a seasonal scale, with only a minor influence of biological activity. Orthophosphate, which had relatively low levels, showed a correlation to $\mathrm{Chl} a$, indicating that it may be limiting. Carbonate sedimentation could be responsible for this.

\section{Acknowledgments}

We thank A. C. Bastos for his scientific coordination of the project and all students, professors and crew for helping collecting the samples. This study was funded by Instituto Estadual do Meio Ambiente do Estado do Espírito Santo (IEMA-ES).

\section{References}

${ }^{1}$ Jensen, A.; Collins K. J.; Lockwood APM. Artificial Reefs in European Seas, $5^{\text {th }}$ Ed., 2000.

2 Bohnsack, J. A.; Sutherland, D. L. Artificial reef research: a review with recommendations for future priorities. Bulletin of Marine Science 1985, 37, 11. [Link]

${ }^{3}$ Bohnsack, J. A. Are high densities of fishes at artificial reefs the result of habitat limitation or behavioral preference? Bulletin of Marine Science 1989, 4, 4631. [Link]

${ }^{4}$ Hueckel, G. J.; Buckley R. M.; Benson B. L. Mitigating rocky habitat loss using artificial reefs. Bulletin of Marine Science 1989, 44, 913. [Link]

${ }^{5}$ Bombace, G.; Fabi, G.; Fiorentini, L. Census results on artificial reefs in the Mediterranean Sea. Bollettino di Oceanologia Teorica ed Applicata 1993, 11, 257. [Link]

${ }^{6}$ Pickering, H.; Whimarsh, D.; Jensen, A. Artificial reefs as a tool to aid rehabilitation of coastal ecosystems: investigating the potential. Marine Pollution Bulletin 1998, 37, 505. [CrossRef]

${ }^{7}$ Miller, M. W. Using ecological processes to advance artificial reef goals. ICES Journal of Marine Science 2002, 59, 27. [CrossRef]

${ }^{8}$ Milon, J. W. Economic evaluation of artificial habitat for fisheries: progress and challenges. Bulletin of Marine Science 1989, 44, 831. [Link]

${ }^{9}$ Szmant, A. M.; Forrester A. Water column and sediment nitrogen and phosphorus distribution patterns in the Florida Keys, USA. Coral Reefs 1996, 15, 21. [Link]

${ }^{10}$ Aminot, A.; Chaussepied, M. Manuel des analyses chimiques en milieu marin. Brest: CNEXO, 1983. 
${ }^{11}$ Barroso, G. F.; Littlepage, J. Protocolo para análise de clorofila-a e feopigmentos pelo método fluorimétrico (fluorímetro TD-700). Programa Brasileiro de Intercâmbio em Maricutura Monitoramento Ambiental. Vitória, 1998.

${ }^{12}$ Rezende, C. E.; Andrade, L.; Suzuki, M. S.; Faro, B. C. M. T; Gonzalez, A. S. M; Paranhos, R. Hidroquímica. In: Valentin, J. L. editor. Características hidrobiológicas da região central da Zona Econômica Exclusiva brasileira (Salvador, BA, ao Cabo de São Tomé, RJ). Brasília: MMA, 2006, 31.

${ }^{13}$ Gaeta, S. A.; Lorenzzetti, J. A.; Miranda, L. B.; Susini-Ribeiro, S. M.; Pompeu, M.; Araujo, C. E. S. A. The Vitoria eddy and its relation to the phytoplankton biomass and primary productivity during the austral fall of 1995. Archive of Fishery and Marine Research 1999, 47, 253. [Link]

${ }^{14}$ Wolanski, E.; Asaeda, T.; Tanaka, A.; Deleersnijder, E. Three-dimensional island wakes in the field, laboratory experiments and numerical models. Continental Shelf Research 1996, 16, 1437. [CrossRef]

${ }^{15}$ Falcão, M.; Santos, M. N.; Vicente, M.; Monteiro C. C. Biogeochemical processes and nutrient cycling within an artificial reef off southern Portugal. Marine
Environmental Research 2007, 63, 429. [CrossRef] [PubMed]

${ }^{16}$ Coutinho, R.; Ribeiro, P.; Kjerfve, B.; Knoppers, B.; Muehe, D.; Valentin, J. L. Araruama: uma lagoa ameaçada. Ciência Hoje 1999, 25, 24. [Link]

${ }^{17}$ Schmid, C. H.; Schafer, H.; Podesta, G.; Zenk, $\mathrm{W}$. The Vitoria eddy and its relation to the Brazil current. Journal of Physical Oceanography 1995, 25, 2532. [CrossRef] ${ }^{18}$ Castro B. M.; Miranda L. B. Physical oceanography of the western Atlantic continental shelf located between 4 o N and 34으, Coastal segment (4, W). In: Robinson AR and Brink KH. The Sea 1998, 209. [Link]

${ }^{19}$ Braga, E. S.; Müller, T. J. Observation of regeneration of nitrate, phosphate and Silicate during upwelling off Ubatuba, Brazil, $23^{\circ} \mathrm{S}$. Continental Shelf Research 1998, 18, 915. [CrossRef]

${ }^{20}$ Rasheed, M.; Bradan, M. I.; Richter, C.; Huettel M. Effect of reef framework and bottom sediment on nutrient enrichment in a coral reef of the gulf of aqaba, red sea. Marine Ecology 2002, 239, 277. [Link]

${ }^{21}$ Ayukai T. Temporal variability of the nutrient environment on davies reef in the central great barrier reef, Australia. Pacific Science 1993, 47, 171. [Link] 